\title{
IMPLEMENTATION OF THE WAHDAH METHOD IN IMPROVING STUDENTS' ABILITY TO MEMORIZE THE QUR'AN
}

\author{
Nofika Ria Nur Farida1, Muhammad Anas Ma`arif², Ari Kartiko³, \\ Institut Pesantren Kh. Abdul Chalim Pacet Mojokerto, Indonesia \\ Email:nofikaria99@gmail.com, anasdt16@gmail.com. Ari.kartiko5@gmail.com
}

\begin{abstract}
This article aims to analyze and explain: Planning, implementing and evaluating the wahdah method in improving the ability to memorize the Qur'an in junior high school students based on the Amanatul Ummah Islamic Boarding School. This article uses a qualitative approach with the type of case study research. Data was collected by using field observation, interview and documentation techniques. Data analysis techniques include data collection, data presentation and data verification. From the analysis of research data, the results of this article are as follows: (1) the planning of the wahdah method in the Amanatul Ummah Islamic Boarding School-Based Junior High School is the division of groups or class divisions according to their abilities. (2) implementation of the wahdah method help make it easier for students to memorize by reading verses of the Qur'an with tartil repeatedly, memorizing verse by verse and tarqiq. (3) The evaluation is that if students memorize one juz, they will be tested with an ustadz/ustadzah other than their class supervisor. The next research recommendation is about the strategy of implementing the wahdah method with a comparison of taqrir, murojaah will result in better memorizing the Qur'an.
\end{abstract}

Keywords: Wabdab Method, Memorizing the Qur'an, Islamic Boarding School.

\section{INTRODUCTION}

Memorizing the Qur'an also has benefits for the creation of a religious atmosphere in the environment of memorizing the Qur'an. Where when the memorizers of the Qur'an gather, it is certain that their activities create a religious atmosphere1. In accordance with the words of the Prophet that when there are a group of people who are reading the Qur'an, it will create a calm atmosphere, the mercy of Allah will always be with them and the angels will surround them. In memorizing the Qur'an it is not difficult but requires extra patience because it is not only memorizing but also maintaining the memorization and having to be patient in passing trials or obstacles while memorizing it. ${ }^{2}$

1 Ahmad Falah, "Analisis Sistem Pendidikan Islam Berbasis Pesantren Anak-Anak Tahfiz Al-Qur'ân Raudhatul Falâh Bermi Gembong Pati Jawa Tengah," Edukasia: Jurnal Penelitian Pendidikan Islam 14, no. 1 (June 24, 2019): 97-124, https://doi.org/10.21043/edukasia.v14i1.3632.

2 Ahmad Salim Badwilan, Cara Mudah Bisa Menghafal Al-Qur'an, ed. Zainul Arifin el-Basyier (Jogjakarta, 2010), 29. 
In memorizing the Qur'an, one thing that needs to be believed is that the Qur'an brings blessings. This has been stated in the Qur'an itself in four places, including: surah alAn'am: 29, 155, surah al-Anbiya': 50 and sura Shad: 29.3 Blessing means having a lot of goodness towards something. The form of the blessing of the Qur'an is not only material but non-material. This form of non-material blessing in the blessing of the Qur'an will eventually have an impact on the material. 4 The proof is that many Al-Qur'an Islamic boarding schools are growing and advancing. That is proof that all things directly related to the Qur'an are blessed. 5

Memorizing the Qur'an must be disciplined and sustain to adding the memorization and always enthusiastic every time and use every time well to learn the Qur'an. Must reduce activities that are not too important so that they must maximize their free time by using those related to the Qur'an such as memorizing, repeating rote memorization or understanding its meaning 6 .

During the memorization process, sometimes they feel quick to memorize the verses of the Qur'an but also quickly lose it, but this is very natural because the memorizers of the Qur'an must feel that way. Therefore we must really take care not to quickly disappear in our memories. At this time there are still many millions and even thousands of Muslims who memorize the Qur'an it proves that memorizing the Qur'an is easy. Even children before adulthood have memorized the Qur'an. From generation to generation the tahfidzul qur'an program is getting serious attention. Formal and non-formal educational institutions have tahfidzul qur'an programs to foster their students to memorize the Qur'an7.

However, memorizing the Qur'an is not as easy as turning the palm of the hand. Every problem experienced by the memorizers of the Qur'an must be different, such as difficulty memorizing because of many similar verses, mental disorders, environmental disturbances or many other activities. But every difficulty and difficulty faced by memorizing the Qur'an must be passed because it will encourage more active and serious in memorizing it 8 .

Especially in today's sophisticated era, there are various methods of memorizing the Qur'an to help make it easier to memorize it. The method is very important because with the method, the memorization process will be programmed and improve memorization to be more effective. The method is very helpful for memorizing the Qur'an to successfully memorize easily and in a fast time, but not everyone can do it because it depends on the method or method used in memorizing.

\footnotetext{
3 Al-Qur`an (Jakarta: Kementerian Agama RI, 2010).

${ }_{4}^{4}$ Ahsin Sakho Muhammad, Menghafalkan Al-Qur'an (Jakarta, 2017), 21.

5 Iqlima Zahari, "Pembelajaran Tahfizh Al Qur'an Pesantren Nurul Huda Mergosono Malang," Ta'allum: Jurnal Pendidikan Islam 5, no. 1 (2017): 53-66.

6 Abdulai Abukari, "Education of Women in Islam: A Critical Islamic Interpretation of the Quran," Religious Education 109, no. 1 (January 1, 2014): 4-23, https://doi.org/10.1080/00344087.2014.868203; A. H. Bahruddin, Endin Mujahidin, and Didin Hafidhuddin, "Metode Tahfizh Al-Quran Untuk Anak-Anak Pada Pesantren Yanbu'ul Qur'an Kudus Jawa Tengah,” Ta'dibuna 6, no. 2 (2018): 65-75.

7 Marwati, "Implementasi Metode Tatsmur Pada Pembelajaran Tahfidzul Qur'an Di SDIT Mutiarainsani Delangguklaten," Skripsi, 2017, 19.

8 Ali Akbar and Hidayatullah Hidayatullah, "Metode Tahfidz Al-Qur'an Di Pondok Pesantren Kabupaten Kampar," Jurnal Ushuluddin 24, no. 1 (2016): 91, https://doi.org/10.24014/jush.v24i1.1517.
} 
Each method has its own advantages and disadvantages. Likewise, this method does not only teach reading or memorizing it but also guides you to love the Qur'an, read it every day, have targets and enjoy interacting with the Qur'an9. Without a learning method it will be in vain, as well as memorizing the Qur'an. The problem of memorizing the Qur'an starts from interests, talents, environment, time and even the method of memorizing the Qur'an itself. In addition, the problem is how to improve the quality of memorizing the Qur'an, dividing the time to add and repeat memorization ${ }^{10}$. Therefore, in determining the method in tahfidzul qur'an, an appropriate and relevant method is needed. At this time preserving the Qur'an is still being carried out with the development of madrasas, Islamic boarding schools and tahfidz al-Qur'an institutions. Each institution sometimes uses different methods to determine the success of their students in memorizing the Qur'an.

Previous research related to the wahdah method has been studied by Wardatu Haniah, 2020.11 The wabdah method is applied at the basic level (Ibtidaiyah) through the technique of being given a tutorial and after that it is done independently. Furthermore, as a comparison of research Marwati12 applying the tasmur method to elementary school children. Subsequent research by Miftahur Rohman ${ }^{13}$ and Hajarman ${ }^{14}$, used the simai method. From previous research, most of the application is at the elementary level, while this research will be carried out in Islamic boarding school-based junior high schools.

As is the case with the Leading Middle School Institution Based on the Amanatul Ummah Islamic Boarding School which has equipped its students with learning tahfidzul qur'an (memorization of the Qur'an) to create a generation who loves the Qur'an and has good character. Tahfidzul Qur'an is a special program of Amanatul Ummah-Based Junior High Schools. Is a noble program that makes its own attraction for students and teachers.

According to the results of observations made on students of the Amanatul Ummah Superior Junior High School based on pesantren. In these institutions use the method of wahdah in memorizing the Qur'an. The Wahdahi method helps students memorize the Qur'an more easily. so that researchers are interested in knowing in more detail about "The Implementation of the Wahdah Method in Improving the Ability to Memorize the Al-Qur'an in Superior Junior High School Students Based on the Amanatul Ummah Pacet-Mojokerto Islamic Boarding School ": The purpose of this study is to describe and analyze the planning, implementation and evaluation of the wahdah memorization method that has been applied by SMP BP Amanatul Ummah Mojokerto.

9 S K Mufidah, Implementasi Metode Utrujah Dalam Pembelajaran Tabfiz, Al-Qur'an Di SDIT Madani Ekselensia Sidoarjo, 2020, 9.

${ }^{10}$ Mizanul Hasanah, "The Role of Parents in Children Memorizing the Qur'an in Middle School Based on the Amanatul Ummah Islamic Boarding School," Tafkir: Interdisciplinary Journal of Islamic Education 2, no. 2 (July 25, 2021): 139-56, https://doi.org/10.31538/tijie.v2i2.43.

11 Wardatul Haniah, "Implementasi Metode Takrir Dalam Meningkatkan Hafalan Al-Qur'an Peserta Didik Di Madrasah Ibtidaiyah Negeri 6 Jember Tahun Pelajaran 2019/2020” (PhD Thesis, IAIN Jember, 2020).

12 Marwati Marwati, "Implementasi Metode Tatsmur Pada Pembelajaran Tahfidzul Qur'an Di Sdit Mutiarainsani Delangguklaten Tahun Pelajaran 2016/2017” (Solo, IAIN Surakarta, 2017).

13 Miftahur Rohman, "Penerapan Metode Sima'i Dalam Menghafal Al-Qur'an Pada Santri Pondok Pesantren Tahfidzul Qur'an Ta'mirul Islam Lawean Surakarta Tahun 2016” (PhD Thesis, IAIN Salatiga, 2017).

14 Hajarman Hajarman, "Implementasi Metode Sima'i Dan Takrir Dalam Meningkatkan Hafalan al-Qur'an Di Sekolah Dasar Muhammadiyah 1 Bandar Lampung” (Masters, UIN Raden Intan Lampung, 2017), http://repository.radenintan.ac.id/2123/. 


\section{RESEARCH METHODS}

This type of research is qualitative using a case study approach. A case study is a study in which researchers explore a certain phenomenon (case) in a time and activity (program, event, process, institution or social group) and collect detailed and in-depth information using various data collection procedures over a certain period. 1516 .

The research was carried out at the Superior Junior High School Based on the Amanatul Ummah Pacet Islamic Boarding School. The research was carried out at that location for reasons and considerations because it has a tahfidz learning program and one of the institutions that applies the Wahdah method which has the aim of printing the Al-Qur'an (Hafidz) generation. The subjects of this research are the principals, teachers and students of the Superior Junior High School Based on the Amanatul Ummah Islamic Boarding School Mojokerto. While the time of the research was carried out from March to May 2021.

The data collection technique is an effort to observe the variables carefully through the methods of observation, interviews and documentation. Data analysis techniques follow the model Miles Hubberman et al17 namely by 1) data reduction, 2) data presentation and, 3) verification and drawing conclusions. The results that have been obtained will then be analyzed using the concept of memorizing the Qur'an according to Badwilan and elaborated with the results of the latest research on memorizing the Qur'an.

\section{RESULTS AND DISCUSSION}

\section{Planning the Wahdah Method in Junior High Schools Based on the Amanatul Ummah Islamic Boarding School}

Amanatul Ummah Islamic Boarding School-Based Junior High School is a shelter for Islamic boarding schools in which there is a school institution that has a special program, namely Tahfidzul. However, students in the Superior Junior High School Based on the Amanatul Ummah Islamic Boarding School come from different backgrounds so that not all of them memorize the Qur'an immediately. Previously, students had to follow the direction of the ustadz/ustadzah to create effective and efficient learning, so there were things that were planned.

Planning is also called Planning which means a preparation of steps in solving problems or implementing activities so that they are directed towards achieving certain goals. 18 Planning is very important and main in an activity. Planning is a process of things to prepare for future activities to achieve the goals that have been set by Juran. 1920

15 Sri Wahyuningsih, Metode Penelitian Studi Kasus: Konsep, Teori Pendekatan Psikologi Komunikasi Dan Contoh Penelitiannya (Bangkalan: UTM Press, 2013), 3.

16 Sugiyono, Metode penelitian pendidikan: (pendekatan kuantitatif, kualitatif dan R \& D) (Bandung: Alfabeta, 2008); Robert K Yin, Case Study Research: Design and Methods, 2013.

17 Matthew B. Miles, A. M. Huberman, and Johnny Saldaña, Qualitative Data Analysis: A Methods Sourcebook, Third edition (Thousand Oaks, Califorinia: SAGE Publications, Inc, 2014).

18 Farida Jaya, "Buku Perencanaan Pembelajaran-Full.Pdf," 2019, 8.

19 J. M. Juran, Juran on Quality by Design: The New Steps for Planning Quality into Goods and Services (New York: Toronto : New York: Free Press ; Maxwell Macmillan Canada ; Maxwell Macmillan International, 1992); Jonathan Savage, Lesson Planning: Key Concepts and Skills for Teachers (Routledge, 2014).

${ }_{20}$ Rusdi Ananda, Perencanaan Pembelajaran (Medan: Lembaga Peduli Pengembangan Pendidikan Indonesia (LPPPI), 2019), 1. 
Likewise with learning Tahfidzul Qur'an so that the learning process runs smoothly and achieves goals well, planning is needed. According to Tika Kartika, the planning steps in memorizing the Qur'an are as follows:21 Determine the target students. 2) Determine learning strategies and methods. 3) Determine the program of learning activities. 4) Determine the timetable for learning

Some things in planning Tahfidzul Qur'an learning if applied will create effective and efficient learning. The Amanatul Ummah Islamic Boarding School-Based Junior High School also applies the Al-Qur'an memorization plan. First, planning in the Superior Junior High School Based on the Amanatul Ummah Islamic Boarding School, namely dividing classes or grouping students according to their abilities. As stated by the school coordinator Afan Hasnan as follows:

"The tabfidz program is grouped into several groups including group $A$ where students can read the Qur'an in short length and recitation well, group B where students can read the Qur'an but the length is short and recitation is not appropriate. group $C$ where students are not fluent in reading the Qur'an and group D where students cannot read the Qur'an." (Interview Data) 22

So planning in the Superior Junior High School Based on the Amanatul Ummah Islamic Boarding School in the first planning there is class division or grouping students according to their abilities. With the division, it will help the learning process to be more effective and efficient. However, in measuring the knowledge of students in class division, there are several things that students do. as expressed by the tahfidz teacher class VIII C Hidayatul Munawaroh as follows: "The grouping of students is done by Bin-Nadhor, namely reading the verses of the Qur'an carefully so that they know the quality of the students in reading the Qur'an. Then judge from the fluency of memorizing the Qur'an and how long it takes students to memorize verses of the Qur'an." 23

The Amanatul Ummah Islamic Boarding School-Based Junior High School has a planning in tahfidz learning planning in class division to measure the ability of students with Bin-Nadhor, fluency in reading the Qur'an in front of the teacher and the speed of memorizing verses that have been determined by the ustadz/his teacher. The existence of class divisions by adjusting their abilities per class will make it easy for each ustadz/ustadzah to focus on guiding their students.

Second, the Amanatul Ummah Islamic Boarding School-Based Junior High School is also in the planning for the memorization target. The target of memorization is also very important in learning Tahfidzul Qur'an because it speeds up memorizing the Qur'an, so it is better to determine the target of memorization. However, the memorization target is adjusted to the abilities of each student. then the existence of a daily memorization target is also needed in order to achieve the memorization target for 2 or 3 years. ${ }^{24}$ Likewise with the expression of

21 Tika Kartika, "Manajemen Pembelajaran Tahfidz Al-QUr'an Berbasis Metode Talaqqi," Islamic Education Manajemen 4, no. 2 (2019): 250.

22 "Data Wawancara, Koordinator SMPU BP Amanatul Ummah, Bapak Affan Hasnan M., M.Pd, Hari Selasa Tanggal 8 Juni 2021 Pukul 08:27,” n.d.

23 "Data Wawancara, Guru Tahfidz Kelas VIII C SMPU BP Amanatul Ummah, Bu Hidayatul Munawaroh, S.Pd.I, Hari Kamis Tanggal 1 April 2021 Pukul 14:00,” n.d.

${ }^{24}$ Sa'dulloh, 9 Cara Praktis Menghafal Al-Qur'an (Jakarta, 2008), 55. 
Muhammad Hafidz, as the coordinator of the Tahfidz Program at SMPU BP Amanatul Ummah as follows: "At SMPU BP Amanatul Ummah in the Tabfidzul Qur'an program, the target for memorizing for 3 years is 9 ju\%. if students can memorize 9 juz or more, they will be graduated"

Likewise with Mrs. Rusdiana Fatmawati, S.Pd, one of her tahfidz teachers also said: "Memories of students deposit their memorization of at least one page and they can even deposit their memorization more than the minimum target" One of the students of Zauhara Putri Rahmania class VIII who has memorized 30 chapters, she said as follows: "Every day I make memorization which will be deposited to the ustadzah at least 1 page but sometimes I can memorize more than one page"

Subsequent planning in determining the memorization target in the Superior Junior High School Based on the Amanatul Ummah Islamic Boarding School is the target for 3 years is 9 juz, while the daily target for students is to deposit memorization to their ustad/ustadzah at least 1 page. By targeting memorization, it will help students to be enthusiastic in memorizing to achieve the targets that have been determined by existing policies.

Third, the next planning in the Superior Junior High School Based on the Amanatul Ummah Islamic Boarding School is to determine the method of learning tahfidz. The method in memorizing the Qur'an is also very important because the method can help so that in memorizing it does not feel difficult and can achieve what you want to achieve. Because by determining the method, it can support the ability of students. ${ }^{25}$

Based on stated the coordinator of the Tahfidzul Qur'an program at the Amanatul Ummah Islamic Boarding School-Based Junior High School Muhammad Hafidz, he revealed: "The tahfidz learning method at SMPU BP Amanatul Ummah can be said to use the wahdah method but there is the development of the wahdah method at SMPU BP Amanatul Ummah."26

The third plan in determining the method is that in the Superior Junior High School Based on the Amanatul Ummah Islamic Boarding School in learning tahfidz using the wahdah method but being developed again by the tahfidz program manager. With the method that has been determined, the learning will be directed. And the last planning is to determine the learning time. This time is also very important because by determining the time, students can optimize their abilities and maximize their time in the Tahfidzul Qur'an learning process and finish quickly.2728. Likewise, the Amanatul Islamic Boarding School-Based Junior High School has determined the time for tahfidz learning. As stated by the tahfidz coordinator of the Superior Junior High School Based on the Amanatul Ummah Islamic Boarding School, Mr. Muhammad Hafidz,. Here he said. "Tabfidz learning at SMPU BP Amanatul Ummah is carried out after the afternoon apple at 13:30 to 16:00"

Apart from being revealed by the tahfidz coordinator of the Amanatul Ummah Islamic Boarding School-Based Junior High School, the school coordinator and his ustadzah said the same thing in the implementation of Tahfidzul Qur'an learning. So that the implementation of tahfidz has been determined when the implementation of tahfidz learning is at the Superior

25 Tika Kartika, "Manajemen Pembelajaran Tahfidz Al-QUr'an Berbasis Metode Talaqqi," 251.

26 "Data Wawancara, Koordinator Program Tahfidz SMPU BP Amanatul Ummah ,Bapak Muhammad Hafidz, S.S., M.Pd.I, Hari Kamis Tanggal 10 Juni 2021 Pukul 15:30,” n.d.

27 Sa'dulloh, 9 Cara Praktis Menghafal Al-Qur'an, 43.

28 Ari Prayoga et al., "Manajemen Pembelajaran Tahfidzul Quran Berbasis Metode Yaddain Di Mi Plus Darul Hufadz Sumedang," Nidhomul Haq : Jurnal Manajemen Pendidikan Islam 4, no. 2 (September 5, 2019): 140-56, https://doi.org/10.31538/ndh.v4i2.326. 
Junior High School Based on the Amanatul Ummah Islamic Boarding School. The implementation of tahfidz learning starts at 13:30 to 16:00.

\section{The Implementation of The Wahdah Method In Improving The Ability To Memorize The Qur'an In Junior High School Students Based On The Amanatul Ummah Islamic Boarding School.}

Furthermore, after planning is prepared in learning, then the next is the implementation of learning. Tahfidz learning in Superior Junior High Schools Based on the Amanatul Ummah Islamic Boarding School to produce quality hafidz and hafidzah generations so that those who are guided by ustadz and ustadz who hafidz are 30 juz. Each ustadz/ustadzah focuses on one class to guide so that students are very concerned about the development of their memorization. If there are students who excel in their tahfid fields, they will be guided to develop them to the national level and even to the ASEAN level.

The schedule for learning tahfidz at the Superior Junior High School Based on the Amanatul Ummah Islamic Boarding School is held at 13:30 to 16:00. However, students must also be smart in managing time in memorizing and repeating memorization at a later time for the implementation of predetermined tahfidz learning.

Memorizing the Qur'an should be able to optimize all abilities and maximize the time it has in order to complete the program to memorize the Qur'an quickly. Therefore, time management is very necessary to be able to anticipate and choose the right time to memorize. ${ }^{29}$ As stated by the coordinator of the tahfidz program, Muhammad Hafidz, he revealed: "In overcoming one of the obstacles is the lack of time to memorize and repeat the memorization of students because it is condensed by other activities, to overcome them, teach students to divide time or manage time".

What was also expressed by one of the students, Zauhara Putri Rahmania, who was in class VIII F: "In memorizing the Qur'an which is condensed with other activities, you have to be smart in finding time, when I have free time or empty hours I use it to make memorization or repeat memorization". So the Superior Junior High School Based on the Amanatul Ummah Islamic Boarding School which is under the auspices of the Islamic Boarding School, the students do not go home and are packed with Islamic boarding school and public school activities. So that you have to be smart in managing time or time discipline is the key to success in memorizing the Qur'an.

One of them is to determine the method. In learning the method is very important because it is very influential in a learning method is a way that has been applied in the plans that have been prepared so that the activities are achieved optimally. If the method used is getting better, the function as a means of achieving goals is also more effective 30 . The steps of the wahdah method in learning tahfidz are as follows: Ahsin W Memorize one by one the verses to be memorized. To achieve initial memorization, each verse is read ten times or twenty times or more, so that this process is able to form a pattern in its image. After

29 Ahsin W, Bimbingan Praktis Menghafal Al-Qur'an (Jakarta, 2005), 58.

30 Akmal Mundiri and Irma Zahra, "Implementasi Metode STIFIn Dalam Meningkatkan Kemampuan Menghafal Al-Qur'an Di Rumah Qur'an STIFIn Paiton Probolinggo," Jurnal Pendidikan Agama Islam (Journal of Islamic Education Studies) 5, no. 2 (2017): 4-5, https://doi.org/10.15642/jpai.2017.5.2.201-223. 
completely memorizing, then proceed to the next verses in the same way, and so on until they reach one face with reflex movements in their mouth.

After that, it is continued to repeat the memorization sheet until it is truly oral capable of producing the verses in one face naturally, or reflex and will eventually form a representative memorization. ${ }^{31}$ Likewise, the Amanatul Ummah Islamic Boarding SchoolBased Junior High School has also determined the learning method, namely using wahdah with the steps above.

As well as the implementation of the tahfidz method which has been revealed by Muhammad Hafidz, the coordinator of the tahfidz program at SMPU BP Amanatul Ummah, he revealed: "In the implementation of the wahdah method in Superior Junior High Schools Based on the Amanatul Ummah Islamic Boarding School, namely the 3T principle, 3T is Tartil, which is reading quietly and slowly, Tabfidz is memorizing verse by verse and Tarqiq is repeating the memorization as much as possible, at least ten times"

Likewise, one of the students also revealed that in the implementation of memorizing the Al-Qur'an Rimadina Listiyan Avava class VII C, he said as follows: "In memorizing it I read it over and over again, then memorized verse by verse and after that repeated the memorization until it was fluent'.

So the implementation of the wahdah method in the Leading Junior High School Based on the Amanatul Ummah Islamic Boarding School has 3T principles, namely: First, Tartil students read the verses of the Qur'an that have been determined calmly, slowly and thoroughly in accordance with the science of recitation. In reading these verses to form a shadow so that it does not feel the students have half memorized. Second, then students begin to memorize verse by verse with tartil when reading previously with tartil so that it is easy to memorize because previously they have read it repeatedly. Third, takrir students will repeat the memorization of verses that have been memorized as much as possible until they are fluent and at least repeat memorization at least ten times. The Wahdah method that has been applied emphasizes repetition. Because repeating memorization will form a pattern in the shadow so that students can memorize the verses and reflexively in their mouth so as to form memorization correctly ${ }^{32}$.

At the Superior Junior High School Based on the Amanatul Ummah Islamic Boarding School which aims to form Hafidz Qur'an students with good memorization quality, besides having a daily learning schedule for memorizing deposits there are weekly activities, monthly activities and annual activities, these activities include: ) Weekly activities, once a week there is reading the Qur'an bil ghaib which is voiced with a microphone. 2) Monthly activities, once a month there is a Qur'an khotmil. An annual activity, once a year the Superior Junior High School Based on the Amanatul Ummah Islamic Boarding School holds a FAQI (Qur'ani

31 Akbar and Hidayatullah, "Metode Tahfidz Al-Qur'an Di Pondok Pesantren Kabupaten Kampar"; Muhammad Kosim et al., "Strengthening Students' Character through Tahfidz Quran in Islamic Education Curriculum," Jurnal Pendidikan Islam 8, no. 1 (September 4, 2019): 69-94, https://doi.org/10.14421/jpi.2019.81.69-94.

32 Miftakhul Ulumiyah, Muhammad Anas Maarif, and M. Afif Zamroni, "Implementation of the Tallaqi, Tafahhum, Tikrar and Murajaah (3T+1M) Method in the Tahfidz Istana Palace Learning Program," Jurnal Pendidikan Islam Indonesia 6, no. 1 (October 14, 2021): 23-33, https://doi.org/10.35316/jpii.v6i1.342. 
Children's Festival), FAQI in which there is a Qur'an Hifdzil competition which is followed by inter-institutions

\section{Evaluation Of The Wahdah Method In Improving The Ability To Memorize The Qur'an In Junior High School Students Based On The Amanatul Ummah Islamic Boarding School}

Edwin in Ramyulis said that evaluation is an action in determining the value of something. Chabib Thoha, quoted by (Mahirah, 2017, p. 258) defines evaluation as a planned activity to find out the state of objects using instruments and the results are compared with benchmarks to obtain conclusions. In general, evaluation is a systematic process to determine the value of something based on certain criteria through assessment. ${ }^{33}$

Therefore, the researcher concludes that evaluation is a process that is used as a benchmark for students to determine the achievement of success in learning. Evaluation is carried out in learning intends to improve or place learning in the right situation ${ }^{34}$. Evaluation of learning outcomes is a planned and continuous activity 35 . There are various forms of evaluation, including: description, objective, verbal, and action tests. However, in memorizing the Qur'an, the evaluation is done by an oral test. The oral test which requires students to answer in oral form in accordance with the questions or orders given.

In memorizing the Qur'an, the evaluation form is that an educator assesses it by instructing students to read or recite the verses of the Qur'an that have been memorized as many as verses that have been determined by the previous educator. ${ }^{36}$ This is usually called talaqi, which is a rote deposit. At the Superior Junior High School Based on the Amanatul Ummah Islamic Boarding School which has implemented the wahdah method, there is also an evaluation to determine the progress of students regarding their tahfid learning. As for the evaluation form, as stated by the school coordinator, Mr. Afan Hasnan M., M.Pd, he revealed: "The evaluation is carried out every three months with reports from the ustadz/ ustadzah on the progress of the students he guides regarding their memorization so that every three months students can change classes by measuring their rote development."

33 Muh Shodiq, S. Suyata, and Sutrisna Wibawa, "Developing Quality Evaluation Instrument for Islamic Senior High School," Jurnal Penelitian Dan Evaluasi Pendidikan 21, no. 2 (December 30, 2017): 189, https://doi.org/10.21831/pep.v21i2.15675; Syamsudin Syamsudin, Muhammad Hidayat Ginanjar, and Moch Yasyakur, "Evaluasi Mutu Pembelajaran Pendidikan Agama Islam (pai) Di Smp Pembangunan Satu (pesat) Kota Bogor Tahun Ajaran 2017/2018," Prosa PAI : Prosiding Al Hidayab Pendidikan Agama Islam 1, no. 2 B (July 3, 2019): 167-78, https://doi.org/10.30868/ppai.v1i2B.468.

34 Matthew T. Brodhead et al., "An Evaluation of a Brief Multiple-Stimulus Without Replacement Preference Assessment Conducted in an Electronic Pictorial Format," Journal of Behavioral Education 25, no. 4 (December 1, 2016): 417-30, https://doi.org/10.1007/s10864-016-9254-3; Choirul Mahfud, "Evaluation of Islamic Education Curriculum Policy in Indonesia," Premiere Educandum: Jurnal Pendidikan Dasar Dan Pembelajaran 9, no. 1 (2019): 34-43.

35 Bahrissalim Bahrissalim and Fauzan Fauzan, "Evaluasi Kurikulum Pelatihan Dalam Meningkatkan Kompetensi Pedagogik Guru Pai Di Balai Diklat Keagamaan Jakarta," Edukasia : Jurnal Penelitian Pendidikan Islam 13, no. 1 (July 25, 2018): 25-52, https://doi.org/10.21043/edukasia.v13i1.2779; Murni Yanto, "Evaluation of Quality Assurance Program," Ijhcm (International Journal of Human Capital Management 1, no. 2 (2017), http://journal.unj.ac.id/unj/index.php/ijhcm/article/view/5739.

36 Khoirul Anwar and Mufti Hafiyana, "Implementasi Metode ODOA (One Day One Ayat) Dalam Meningkatkan Kemampuan Menghafal al-Quran," Jurnal Pendidikan Islam Indonesia, 2018, 187-88, https://doi.org/10.35316/jpii.v2i2.71. 
So that the evaluation of the wahdah method at the Amanatul Ummah Superior Junior High School which has implemented the wahdah method is the form of evaluation which is also carried out in a meeting by the school coordinator and his ustadz/ustadzah for three months by paying attention to the development of his memorization so that if the students develop well and even increase, they can go up. to the superior tahfidz class and vice versa. Likewise, the coordinator of the tahfidz program, Mr. Muhammad Hafidz, said regarding the evaluation of the wahdah method as follows: "The form of evaluation of the wabdab method in tahfidz. learning at the Amanatul Ummah Superior Junior High School is that every student achieves rote memorization, the student is tested by facing the ustadz. / ustadzah examiner"

Furthermore, there is also an evaluation if the student has memorized one juz, then the form of evaluation is that the student will take the exam by facing the ustadz/ustadzah examiner by listening to the one juz that has been memorized. Then the tahfidz teacher, Mrs. Rusdiana Fatmawati, S.Pd, also conveyed her statement as follows: "The evaluation for class XI is that when they are about to graduate from tahfids, they will finish bil ghaib which is listened to by all students and the ustadz/ustadzah of the Amanatul Ummah Superior Middle School"

Furthermore, at the Amanatul Ummah Superior Junior High School the evaluation of students for class XI is an evaluation for three years. So that the form of student evaluation is for three years, namely when graduation will be held, class XI students khataman bil ghaib are voiced with microphones alternately and are listened to by all students and their ustadz/ustadzah.

\section{CONCLUSION}

The planning of the Wahdah Method in improving the ability to memorize the Qur'an in students at the Superior Junior High School Based on the Amanatul Ummah Islamic Boarding School, among others: a) Class division, in class division or grouping students through bin-nadhor tests, quality in reading Al-Qur'an Qur'an and how long it takes to memorize verses of the Qur'an. b) Determine target students, Target each deposit at least 1 page a day and for 3 years at least memorize 9 juz. c) Determine learning strategies and methods, in the Superior Junior High School Based on the Amanatul Ummah Islamic Boarding School using the wahdah method in learning Tshfidzul Qur'an. d) Determine the schedule and time for learning. Tahfidz lessons are held every Monday to Saturday at 13:3016:00.

In implementing the method of wahdah in Superior Junior High Schools Based on the Amanatul Ummah Islamic Boarding School with 3T principles, including: 1) Tartil, reading verses of the Qur'an with tartil repeatedly. 2) Tahfidz, memorizing verse by verse and not changing to memorizing verses before they are fluent. 3) Tarqiq, repeating the memorization of the verses that have been memorized as much as possible until smooth and at least 10 times. The form of evaluation of the Wahdah Method in improving the ability to memorize the Qur'an in students at the flagship junior high school based on the Amanatul Ummah Islamic Boarding School is an oral test when students reach memorization of 1 juz. There is a khataman bil ghoib for grade 9 which is listened to by all students and clerics / clerics of the Superior Junior High School Based on the Amanatul Ummah Islamic Boarding School. However, to improve the ability to memorize the Qur'an at the Superior Junior High School 
Based on the Amanatul Ummah Islamic Boarding School there is a weekly program, namely reading the Qur'an bil ghoib, a monthly program, namely at the beginning of every month holding a Qur'an khotmil and an annual program namely holding a tahfidz competition. between institutions.

\section{REFERENCES}

Abukari, Abdulai. "Education of Women in Islam: A Critical Islamic Interpretation of the Quran.” Religious Education 109, no. 1 (January 1, 2014): 4-23. https://doi.org/10.1080/00344087.2014.868203.

Ahsin W. Bimbingan Praktis Menghafal Al-Qur'an. Jakarta, 2005.

Akbar, Ali, and Hidayatullah Hidayatullah. "Metode Tahfidz Al-Qur'an Di Pondok Pesantren Kabupaten Kampar." Jurnal Ushuluddin 24, no. 1 (2016): 91. https://doi.org/10.24014/jush.v24i1.1517.

Al-Qur`an. Jakarta: Kementerian Agama RI, 2010.

Anwar, Khoirul, and Mufti Hafiyana. "Implementasi Metode ODOA (One Day One Ayat) Dalam Meningkatkan Kemampuan Menghafal al-Quran." Jurnal Pendidikan Islam Indonesia, 2018. https://doi.org/10.35316/jpii.v2i2.71.

Badwilan, Ahmad Salim. Cara Mudah Bisa Menghafal Al-Qur'an. Edited by Zainul Arifin elBasyier. Jogjakarta, 2010.

Bahrissalim, Bahrissalim, and Fauzan Fauzan. "Evaluasi Kurikulum Pelatihan Dalam Meningkatkan Kompetensi Pedagogik Guru Pai Di Balai Diklat Keagamaan Jakarta." Edukasia: Jurnal Penelitian Pendidikan Islam 13, no. 1 (July 25, 2018): 25-52. https://doi.org/10.21043/edukasia.v13i1.2779.

Bahruddin, A. H., Endin Mujahidin, and Didin Hafidhuddin. "Metode Tahfizh Al-Quran Untuk Anak-Anak Pada Pesantren Yanbu'ul Qur'an Kudus Jawa Tengah.” Ta'dibuna 6, no. 2 (2018): 65-75.

Brodhead, Matthew T., Emily A. Abel, Monerah N. Al-Dubayan, Lauren Brouwers, Gina Warren Abston, and Mandy J. Rispoli. "An Evaluation of a Brief Multiple-Stimulus Without Replacement Preference Assessment Conducted in an Electronic Pictorial Format." Journal of Behavioral Education 25, no. 4 (December 1, 2016): 417-30. https://doi.org/10.1007/s10864-016-9254-3.

"Data Wawancara, Guru Tahfidz Kelas VIII C SMPU BP Amanatul Ummah, Bu Hidayatul Munawaroh, S.Pd.I, Hari Kamis Tanggal 1 April 2021 Pukul 14:00,” n.d.

"Data Wawancara, Koordinator Program Tahfidz SMPU BP Amanatul Ummah ,Bapak Muhammad Hafidz, S.S., M.Pd.I, Hari Kamis Tanggal 10 Juni 2021 Pukul 15:30,” n.d.

"Data Wawancara, Koordinator SMPU BP Amanatul Ummah , Bapak Affan Hasnan M., M.Pd, Hari Selasa Tanggal 8 Juni 2021 Pukul 08:27,” n.d.

Falah, Ahmad. "Analisis Sistem Pendidikan Islam Berbasis Pesantren Anak-Anak Tahfiz AlQur'ân Raudhatul Falâh Bermi Gembong Pati Jawa Tengah.” Edukasia: Jurnal Penelitian Pendidikan Islam 14, no. 1 (June 24, 2019): 97-124. https://doi.org/10.21043/edukasia.v14i1.3632. 
Hajarman, Hajarman. "Implementasi Metode Sima’i Dan Takrir Dalam Meningkatkan Hafalan al-Qur'an Di Sekolah Dasar Muhammadiyah 1 Bandar Lampung.” Masters, UIN Raden Intan Lampung, 2017. http:// repository.radenintan.ac.id/2123/.

Haniah, Wardatul. "Implementasi Metode Takrir Dalam Meningkatkan Hafalan Al-Qur'an Peserta Didik Di Madrasah Ibtidaiyah Negeri 6 Jember Tahun Pelajaran 2019/2020.” PhD Thesis, IAIN Jember, 2020.

Hasanah, Mizanul. "The Role of Parents in Children Memorizing the Qur'an in Middle School Based on the Amanatul Ummah Islamic Boarding School." Tafkir: Interdisciplinary Journal of Islamic Education 2, no. 2 (July 25, 2021): 139-56. https://doi.org/10.31538/tijie.v2i2.43.

Jaya, Farida. "Buku Perencanaan Pembelajaran-Full.Pdf," 2019.

Juran, J. M. Juran on Quality by Design: The New Steps for Planning Quality into Goods and Services. New York: Toronto : New York: Free Press; Maxwell Macmillan Canada; Maxwell Macmillan International, 1992.

Kosim, Muhammad, Martin Kustati, Ahmad Sabri, and Mujahidil Mustaqim. "Strengthening Students' Character through Tahfidz Quran in Islamic Education Curriculum.” Jurnal Pendidikan Islam 8, no. 1 (September 4, 2019): 69-94. https://doi.org/10.14421/jpi.2019.81.69-94.

Mahfud, Choirul. "Evaluation of Islamic Education Curriculum Policy in Indonesia." Premiere Educandum: Jurnal Pendidikan Dasar Dan Pembelajaran 9, no. 1 (2019): 34-43.

Marwati. "Implementasi Metode Tatsmur Pada Pembelajaran Tahfidzul Qur'an Di SDIT Mutiarainsani Delangguklaten.” Skripsi, 2017.

Marwati, Marwati. "Implementasi Metode Tatsmur Pada Pembelajaran Tahfidzul Qur'an Di Sdit Mutiarainsani Delangguklaten Tahun Pelajaran 2016/2017." IAIN Surakarta, 2017.

Miles, Matthew B., A. M. Huberman, and Johnny Saldaña. Qualitative Data Analysis: A Methods Sourcebook. Third edition. Thousand Oaks, Califorinia: SAGE Publications, Inc, 2014.

Mufidah, S K. Implementasi Metode Utrujah Dalam Pembelajaran Tahfiz. Al-Qur'an Di SDIT Madani Ekselensia Sidoarjo, 2020.

Muhammad, Ahsin Sakho. Menghafalkan Al-Qur'an. Jakarta, 2017.

Mundiri, Akmal, and Irma Zahra. "Implementasi Metode STIFIn Dalam Meningkatkan Kemampuan Menghafal Al-Qur'an Di Rumah Qur'an STIFIn Paiton Probolinggo.” Jurnal Pendidikan Agama Islam (Journal of Islamic Education Studies) 5, no. 2 (2017): 201. https://doi.org/10.15642/jpai.2017.5.2.201-223.

Prayoga, Ari, Rizqia Salma Noorfaizah, Yaya Suryana, and Mohammad Sulhan. "Manajemen Pembelajaran Tahfidzul Quran Berbasis Metode Yaddain Di Mi Plus Darul Hufadz Sumedang." Nidhomul Haq: Jurnal Manajemen Pendidikan Islam 4, no. 2 (September 5, 2019): 140-56. https://doi.org/10.31538/ndh.v4i2.326.

Rohman, Miftahur. "Penerapan Metode Sima'i Dalam Menghafal Al-Qur'an Pada Santri Pondok Pesantren Tahfidzul Qur'an Ta'mirul Islam Lawean Surakarta Tahun 2016.” PhD Thesis, IAIN Salatiga, 2017.

Rusdi Ananda. Perencanaan Pembelajaran. Medan: Lembaga Peduli Pengembangan Pendidikan Indonesia (LPPPI), 2019. 
Sa'dulloh. 9 Cara Praktis Menghafal Al-Qur'an. Jakarta, 2008.

Savage, Jonathan. Lesson Planning: Key Concepts and Skills for Teachers. Routledge, 2014.

Shodiq, Muh, S. Suyata, and Sutrisna Wibawa. "Developing Quality Evaluation Instrument for Islamic Senior High School." Jurnal Penelitian Dan Evaluasi Pendidikan 21, no. 2 (December 30, 2017): 189. https://doi.org/10.21831/pep.v21i2.15675.

Sugiyono. Metode penelitian pendidikan: (pendekatan kuantitatif, kualitatif dan $\mathrm{R} \& \mathrm{D}$ ). Bandung: Alfabeta, 2008.

Syamsudin, Syamsudin, Muhammad Hidayat Ginanjar, and Moch Yasyakur. "Evaluasi Mutu Pembelajaran Pendidikan Agama Islam (pai) Di Smp Pembangunan Satu (pesat) Kota Bogor Tahun Ajaran 2017/2018." Prosa PAI : Prosiding Al Hidayah Pendidikan Agama Islam 1, no. 2B (July 3, 2019): 167-78. https://doi.org/10.30868/ppai.v1i2B.468.

Tika Kartika. "Manajemen Pembelajaran Tahfidz Al-QUr'an Berbasis Metode Talaqqi." Islamic Education Manajemen 4, no. 2 (2019).

Ulumiyah, Miftakhul, Muhammad Anas Maarif, and M. Afif Zamroni. "Implementation of the Tallaqi, Tafahhum, Tikrar and Murajaah $(3 \mathrm{~T}+1 \mathrm{M})$ Method in the Tahfidz Istana Palace Learning Program.” Jurnal Pendidikan Islam Indonesia 6, no. 1 (October 14, 2021): 23-33. https://doi.org/10.35316/jpii.v6i1.342.

Wahyuningsih, Sri. Metode Penelitian Studi Kasus: Konsep, Teori Pendekatan Psikologi Komunikasi Dan Contoh Penelitiannya. Bangkalan: UTM Press, 2013.

Yanto, Murni. "Evaluation of Quality Assurance Program.” Ijhcm (International Journal of Human Capital Management $1, \quad$ no. 2017 ). http://journal.unj.ac.id/unj/index.php/ijhcm/article/view/5739.

Yin, Robert K. Case Study Research: Design and Methods, 2013.

Zahari, Iqlima. "Pembelajaran Tahfizh Al Qur'an Pesantren Nurul Huda Mergosono Malang." Ta'allum: Jurnal Pendidikan Islam 5, no. 1 (2017): 53-66. 